\title{
KRITIK SOSIAL DALAM PUISI DARI CATATAN SEORANG DEMONSTRAN (TAUFIQ ISMAIL) DAN PUISI SIKAP (WIJI THUKUL)
}

\author{
Veronica Chervinnita $^{1 *}$, Salmaa Athira ${ }^{2}$, Gres Grazia Azmin ${ }^{3}$ \\ Universitas Negeri Jakarta \\ veronicachervinnita@gmail.com
}

\begin{abstract}
Abstrak
Puisi, salah satu bentuk karya sastra, merupakan sebuah proses dan produk kreativitas penciptaan seorang penulis dalam menyampaikan pandangan dan gagasannya. Penelitian ini merupakan kajian dua puisi menggunakan pendekatan Sosiologi Sastra. Penelitian ini bertujuan untuk menemukan bagaimana sebuah karya puisi digunakan sebagai alat kritik sosial. Puisi yang berjudul "Dari Catatan Seorang Demonstran" karya Taufiq Ismail dan "Puisi Sikap" karya Wiji Thukul dijadikan sebagai objek penelitian ini. Penelitian ini menggunakan metode kualitatif dengan teknik analisis deskriptif. Pengumpulan data dilakukan dengan membaca data, memilah data, dan mencatat data yang berkaitan dengan aspek kritik sosial. Hasil dari penelitian ini yaitu untuk menunjukkan bahwa objek penelitian ini menggambarkan realitas sosial di masyarakat: 1) Keresahan masyarakat pada keadaan negara yang krisis politik, ekonomi, dan sosial; 2) Dampak dari penyimpangan prinsip demokrasi negara. Kesimpulan yang ditemukan bahwa kekacauan dalam politik dan HAM berdampak besar pada kehidupan masyarakat. Salah satu media masyarakat untuk memperjuangkan aspirasinya adalah karya puisi.
\end{abstract}

Kata Kunci: Puisi, Sosiologi Sastra, Kritik Sosial

\section{PENDAHULUAN}

Sastra adalah sebuah kegiatan kreatif dan imajinatif. Karya sastra dihasilkan oleh nilai estetis. Menurut Setyorini (2014:1-2), karya sastra merupakan sebuah karya yang pada hakikatnya dibuat dengan mengedepankan aspek keindahan di samping keefektifan penyampaian pesan. Kehadiran sastra adalah sebagai hasil dari perenungan seorang pengarang mengenai fenomena yang ada, tetapi bisa juga sastra itu hadir sebagai cara pengarang untuk menuangkan ide dan gagasannya untuk dinikmati seluruh kalangan masyarakat. Pengertian sastra dalam Kamus Umum Bahasa Indonesia, ada lima penjelasan yang tercantum dari kata 'sastra': (1) bahasa khusus dalam kitab dan bukan bahasa seharihari; (2) karya kesenian yang diwujudkan dengan bahasa; (3) kitab suci Hindu atau ilmu pengetahuan; (4) pustaka atau buku; dan (5) tulisan atau huruf (Darminta, 1991:875). Kemudian ada penjelasan tambahan dalam Kamus Besar Bahasa Indonesia (KBBI), yaitu kesusastraan merupakan karya tulis yang memiliki keunggulan (asli, artistik indah), seperti roman, cerpen, drama, dan epik.

Karya sastra muncul sebagai objek pengetahuan sui generis, yang mempunyai status ontologis khusus. Sebuah karya sastra bukanlah suatu benda nyata, mental, atau ideal. Karya sastra adalah sistem norma dari konsep-konsep ideal yang intersubjektif. Karya sastra merupakan sebuah bentuk ciptaan komunikatif oleh penulis dengan melibatkan unsur seni. Karya sastra bisa menjadi sarana penulis menyampaikan isi pikiran dan perasaan penulis pada pembaca. Karya sastra menceritakan tentang kisah dari ragam sudut pandang. Puisi adalah salah satu bentuk karya sastra yang dapat dinikmati semua kalangan.

Puisi merupakan karya bebas yang mengungkapkan ide, gagasan, serta perasaan menulis dalam rupa tulisan. Hudson dalam Aminuddin (2011:134) mengatakan bahwa puisi adalah salah satu cabang sastra yang menggunakan kata-kata sebagai media penyampaian untuk membuahkan ilusi dan imajinasi, seperti halnya lukisan yang menggunakan garis dan warna dalam menggambarkan gagasan pelukisnya. Menurut Ahmad dalam Suryaman dan Wiyatmi (2012:13) puisi itu merupakan sebuah emosi, imajinasi, pemikiran, ide, nada, irama kesan pancaindra, susunan kata, kata-kata kiasan, kepadatan, dan perasaan yang tercampur-baur. Puisi adalah pengalaman dari penyair, yaitu pengalaman ketika menciptakan puisi tersebut, ada yang sadar atau tidak sadar. Dapat kita ambil garis besar bahwa pengertian dari puisi yaitu puisi merupakan salah satu karya sastra yang dituang menggunakan kata-kata 
KRITIK SOSIAL DALAM PUISI DARI CATATAN .... $\mid 19$ sebagai medianya yang berasal dari imajinasi, pikiran, emosi, atau perasaan si penulis. Maka puisi juga dapat disebut sebagai refleksi dari pengalaman, budaya, serta struktur lainnya dari penulis.

Terdapat beberapa pendekatan yang bisa digunakan untuk mengkaji isi puisi. Salah satunya yaitu pendekatan sosiologi sastra. Sosiologi itu sendiri adalah sebuah ilmu yang mempelajari dan meneliti berbagai bidang kehidupan dan masalah sosial masyarakat, seperti masalah lingkungan hidup, kemiskinan, dan lainnya. Fokus perhatian sosiologi karya sastra adalah pada isi karya sastra, tujuan serta hal lainnya yang tersirat dalam karya sastra itu sendiri dan yang berkaitan dengan masalah sosial (Wellek \& Warren, 1995). Ratna (2003:2) berpendapat bahwa sosiologi sastra adalah sebuah pemahaman terhadap karya sastra dengan mempertimbangkan aspek-aspek kemasyarakatannya. Di dalamnya diterapkan bahwa sosiologi sastra meneliti suatu karya sastra berdasarkan pemahaman terhadap totalitas karya sastra dan disertai dengan berbagai aspek kemasyarakatan yang terkandung di dalamnya. Soekanto (2012: 314) menyatakan bahwa masalah sosial timbul dari kekurangan-kekurangan dalam diri manusia atau kelompok sosial yang sumbernya pada faktor ekonomis, psikologis, biologis, dan kebudayaan.

Masalah tersebut menjadi tumpuan bagi para pengarang dalam mengubah karya sastra sebagai media untuk mengkritik. Kritik muncul karena hadirnya masalah sosial. Sumardjo (1984:2) berpendapat bahwa sebuah karya yang lahir di kalangan masyarakat berawal dari desakan emosional dari masyarakat seperti kegelisahan, harapan, serta penderitaan yang dialami masyarakat. Aspirasi tersebut menjadi bagian dari diri pengarang. Aspirasi tersebut yang menghadirkan sebuah kritik. Kritik yang dihasilkan pengarang menjadi sebuah media komunikasi antara pengarang atau masyarakat dengan tujuan meluruskan sebuah sistem yang sedang berjalan (Oksinata, 2010:33). Kritik sosial merupakan disiplin ilmu mengenai kajian hal-hal yang berkaitan dengan kritik, kritik itu sendiri berarti suatu tindakan untuk mengkritisi suatu pokok kejadian dalam kehidupan masyarakat. Dengan demikian, kritik sosial merupakan wujud dari perlawanan terhadap pendapat atau keadaan yang sedang terjadi di dalam masyarakat. Seperti yang telah diungkapkan oleh Sapardi (1979:1), Para sastrawan menyalurkan perlawanannya dalam sebuah karya sastra. Karya sastra yang nantinya menjadi sebuah pandangan tak terkuak dalam buku sejarah sekolah.

Pada dasarnya, kehadiran karya sastra memiliki keterikatan pada manusia, baik oleh pengarang maupun pembaca. Keterkaitan tersebut berhubungan dengan kehidupan yang dialami manusia. Salah satu kehidupan yang dialami adalah kehidupan sosial manusia. Sastra yang memperkenalkan kehidupan sebagian besar berupa kenyataan sosial walaupun karya berupa subjektif dan tiruan (Wellek \& Warren, 1990:109). Taufiq Ismail merupakan sosok penyair dan juga tokoh sastrawan angkatan 66. Taufiq Ismail dikenal dengan karya yang la ciptakan berhubungan dengan sosial manusia. Salah satu karya yang pernah la hasilkan diterbitkan ke dalam sebuah buku kumpulan puisi yang berjudul Benteng dan Tirani. Buku Benteng dan Tirani adalah kumpulan puisi yang berisikan siaran kejadian krisis kedudukan politik, ekonomi, serta budaya di Indonesia. Puisi-puisi ini ditulis oleh penulis dalam masa 6 tahun. Banyak puisi milik Taufiq Ismail ini yang merupakan siaran demonstrasi pada zaman kejadian tersebut. Penulis mengungkapkan bahwa penulis ikut turun ke jalan sebagai demonstran pada tahun 1965 hingga tahun 1966. Itulah mengapa puisi yang tertera tahun 1965 dan 1966 mengandung kisah dan kritik dari para demonstran, baik mahasiswa maupun rakyat biasa, dalam melawan kekuasaan sewenang-wenang di Indonesia. Penulis memilih karya milik Taufiq Ismail yang berjudul Dari Catatan Seorang Demonstran sebagai objek penelitian.

Selain Taufiq Ismail, penulis juga memilih puisi berjudul Puisi Sikap, karangan seorang penyair Wiji Thukul sebagai objek dari penelitian. Wiji Thukul merupakan penyair yang berasal dari Solo, lahir pada tanggal 26 Agustus 1963. la dibesarkan di sebuah kampung yang sebagian besar warganya adalah buruh dan tukang becak. Oleh karena itu, puisi-puisi Wiji Thukul berisi tentang suka duka rakyat miskin. Dalam puisinya, Wiji menyuarakan kesenjangan ekonomi yang menjadi dampak dari kebijakan politik ekonomi pemerintah Orde Baru. Di masa itu, Wiji Thukul dianggap berbahaya karena puisipuisinya penuh dengan ideologi revolusioner. Akibatnya, Wiji kerap kali berurusan dengan militer. Wiji Thukul telah hilang pada sekitar tahun 1998 dan segala aktivitas sosialnya pun berakhir.

Peneliti menggunakan penelitian sebelumnya sebagai acuan dalam meneliti karya Taufiq Ismail seperti yang pernah dibahas oleh Syahlulya Lully (2018) dengan judul "Kritik Sosial dalam Kumpulan Puisi Karya Taufiq Ismail." Penelitian Syahlulya Lully (2018) ini bertujuan untuk mendeskripsikan keadaan sosial serta kritik yang disampaikan oleh Taufiq Ismail melalui karya puisi dalam buku Kumpulan Puisi : Tirani dan Benteng. Hasil dari penelitian yang didapatkan oleh Syahlulya Lully (2018) bahwa sastra dan masyarakat memiliki hubungan erat. Sastra menjadi sebuah media untuk 
mengungkapkan ekspresi baik berlandas aspek sosial maupun protes terhadap keadaan yang tidak selaras.

Dalam meneliti karya Wiji Thukul, peneliti menggunakan jurnal Pratikno (1998) berjudul "Keretakan Otoritarianisme Orde Baru dan Prospek Demokratisasi" yang membahas situasi dan keadaan negara Indonesia pada tahun 1998. Dengan jurnal ini, peneliti dapat mengetahui situasi pada masa tersebut sekaligus mengaitkannya dengan puisi karya Wiji Thukul yang ditulis pada era yang sama. Hasil dari penelitian Pratikno (1998) yaitu dalam menemukan jawaban mengapa otoritarianisme Orde Baru mengalami keretakan, dan bagaimana prospek demokratisasi di Indonesia yang diwariskan Orde Baru. Selain jurnal tersebut, peneliti juga menggunakan sebuah penelitian yang berjudul "Kritik Sosial Dalam Kumpulan Puisi Aku Ingin Jadi Peluru karya Wiji Thukul (Kajian Resepsi Sastra)" oleh Hantisa Oksinata. Penelitian ini bertujuan untuk mendeskripsikan unsur batin dan kritik sosial serta resepsi pembaca pada puisi Aku Ingin Jadi Peluru. Simpulan yang dapat ditarik dalam analisis tersebut yaitu puisi Aku Ingin Jadi Peluru secara umum memuat tema tentang kondisi keseharian masyarakat kecil yang tertindas, perasaan yang dialami penyair, dan suasana dalam puisi-puisinya bernada melawan.

Dengan menganalisis puisi Dari Catatan Seorang Demonstran karya Taufiq Ismail dan Puisi Sikap karya Wiji Thukul, penulis berharap dapat menemukan cerminan kritik sosial di kedua era puisipuisi tersebut diciptakan dengan membandingkan keduanya.

\section{METODE PENELITIAN}

Bentuk penelitian ini adalah deskriptif kualitatif dengan metode analisis isi. Maka penelitian ini mendeskripsikan, menganalisis, dan menafsirkan data. Data yang dikumpulkan langsung dari sumbernya, peneliti menjadi bagian dari instrumen pokok analisisnya dan data berupa kata-kata dalam kalimat atau gambar yang mempunyai arti (Sutopo, 2006:40). Dengan demikian, objek yang dikaji dan dipaparkan dalam bentuk kata-kata. Metode analisis isi, dari yang telah dijelaskan di atas, penelitian ini menggunakan pendekatan sosiologi sastra yang dikenalkan oleh Sapardi Djoko Damono dalam Wahyuningtyas dan Santoso (2011:20). Sosiologi sastra adalah ilmu pengetahuan yang mempelajari masyarakat dalam keseluruhannya, terutama yang berhubungan dengan aspek-aspek masyarakat yang menyangkut dengan interaksi di lingkungannya. Sumber data penelitian ini adalah puisi Taufiq Ismail yang berjudul Dari Catatan Seorang Demonstran dan puisi Wiji Thukul yang berjudul Puisi Sikap. Teknik pengumpulan data penelitian ini dengan membaca data, memilah data, mencatat data yang akan digunakan, dan menganalisis data. Teknik analisis data yaitu pemaknaan data secara harfiah sesuai dengan pandangan sastra dan sejarah serta penarikan kesimpulan.

\section{HASIL DAN PEMBAHASAN}

\section{Kritik Sosial Puisi Taufiq Ismail dan Wiji Thukul Dalam Perspektif Sosiologis}

\section{A. Puisi “ Dari Catatan Seorang Demonstran” karya Taufiq Ismail}

Puisi-puisi Taufiq Ismail yang bertemakan perlawan ini merupakan karya yang dilandasi dengan kritiknya pada penguasa. Kritik sekaligus sindiran itu tertera pada baris "Di sinilah keberanian diuji" dan "Kebenaran dicoba dihancurkan", Taufiq Ismail menyindir pemerintah negara bahwa kebenaran di negara sedang dicoba untuk dihancurkan. Di sini beliau juga sekaligus memberi sebuah motivasi bagi masyarakat untuk berani memberi aspirasi serta perlawanan.

Pada tahun 1966, puisi ini ditulis Taufiq Ismail, negara Indonesia sedang dalam masa transisi dari Orde Lama menuju Orde Baru. Pada masa ini, pemerintahan Orde Baru tercatat memiliki pelanggaran hak asasi manusia (HAM) dan korupsi yang sangat tinggi. Sebelumnya, Pada masa tersebut terjadi kekacauan yang tak hanya dari segi HAM dan politik, tetapi juga segi ekonomi maupun sosial. Indonesia mengalami permasalahan ekonomi yang mana harga pokok melonjak, yaitu mengalami inflasi 650\%. Selain itu, terjadinya peristiwa 30 September 1965 yang ditunggangi PKI. Peristiwa tersebut membuat nama PKI meresahkan masyarakat karena dianggap menghancurkan ideologi Pancasila, termasuk kabinet Dwikora pada zaman orde lama karena banyak anggota dari kabinet tersebut yang juga merupakan anggota PKI. Rakyat memprotes terhadap gugatan keangkuhan politik Indonesia yang disebut Tiga Tuntutan Rakyat (TRITURA): mengenai pembubaran PKI; perombakan kabinet dwikora; Veronica Chervinnita, Salmaa Athira, Gres Grazia Azmin 
KRITIK SOSIAL DALAM PUISI DARI CATATAN .... $\mid 21$ dan menurunkan harga pokok. Masyarakat dan mahasiswa menyampaikan aspirasinya melalui unjuk rasa dengan melahirkan beberapa organisasi seperti KAMI, KAGI, KAPPI, KAWI, KASI, dan sebagainya yang kini dikenal dengan sebutan Angkatan 66.

Angkatan 66 turun ke jalan menyerukan tuntutannya dan mengarak spanduk-spanduk TRITURA dari daerah ke daerah lainnya. Pada bait "Inilah peperangan Tanpa jenderal, tanpa senapan" terungkap bahwa perlawanan masyarakat kepada kekuasan tirani tidak ditunggangi dengan jenderal dan bahkan masyarakat tidak berbekal senapan. Jenderal merupakan pangkat tertinggi yang dapat dicapai oleh seorang perwira di Angkatan Darat, yang mana memiliki kesempatan tinggi untuk memenangkan perlawanan. Hal ini berbanding terbalik dengan para penguasa yang dengan mudah memenangkan perlawanan karena menggandeng kekuasaan. Bait "Pada hari-hari yang mendung Bahkan tanpa harapan" menggambarkan situasi dan isi perasaan para demonstran yang turun ke jalan. Mereka tidak mempunyai harapan jelas bahwa suaranya akan didengar oleh para penguasa. Puisi ini adalah bentuk sindiran dan kritikan dari Taufiq Ismail kepada para penguasa yang berkuasa sewenang-wenang dan tidak memperhatikan suara rakyat.

\section{B. Puisi “Puisi Sikap” (1997) karya Wiji Thukul}

Pada tahun 1997 puisi ini ditulis oleh Wiji Thukul. Saat itu sedang terjadi peristiwa krisis moneter di Indonesia, yang artinya keadaan keuangan Indonesia sedang mengalami krisis. Di samping hal perekonomian, politik Indonesia pun mengalami kendala dalam prinsip negara. Sistem pemerintahan demokrasi yang seharusnya dianut Indonesia, justru kenyataannya menganut sistem otoritarian karena sangat minimnya keterlibatan masyarakat dan dominannya peran pemerintah. Partai Golkar dijadikan sebagai kendaraan politik yang digunakan oleh Soeharto untuk mengamankan setiap keputusan politik di DPR. Hak-hak dasar warga negara pun terbatas.

Kekuasaan politik Orde Baru itu bersumber dari empat hal utama, yaitu represi fisik dan hukum, klientelisme ekonomi, wacana politik partikularistik yang mendukung otoritarianisme, dan pengembangan korporatisme negara (Pratikno, 1996). Empat sumber daya politik tersebut menjadi sumber energi yang besar bagi elit Orde Baru di bawah Soeharto untuk membangun otoritarianisme politik sampai awal 1990-an. Mulai dengan awal 1990-an, isu mengenai pelanggaran hak asasi manusia (HAM) pun tinggi, tetapi hal itu disadari oleh elit politik di Indonesia akan mempermudah bagi negara maju untuk melakukan tekanan politik dan ekonomi.

Dalam 4 baris pertama pada puisi ini, dapat kita lihat sindiran dan kritikan yang terkait pada keadaan politik:

\section{maunya mulutmu bicara terus tapi tuli telingamu tak mau mendengar maumu aku ini jadi pendengar terus Bisu}

Wiji Thukul menekankan bahwa la sebagai masyarakat tidak punya kendali untuk bersuara, hal ini terkait dengan sistem otoriter yang terjadi. Segala bentuk media pun dikontrol dan diawasi pemerintah, jelas bahwa kehidupan demokrasi dikekang.

\section{kamu memang punya tank}

Kekuatan militer (ABRI) digunakan Soeharto untuk menekan masyarakat yang melakukan perlawanan ataupun mengkritik rezim atas kepemimpinannya yang otoriter. Pada empat (4) bait di atas, kritikan Wiji Thukul terlihat pada kata "Tank" untuk menyindir kekuatan militer (ABRI).

\section{tapi salah besar kamu kalau karena itu aku lantas manut}

Pada baris di atas, Wiji Thukul mengkritik dengan menggunakan kalimat yang cenderung menentang bahwa ia sebagai masyarakat yang dibungkam tidak akan menjadi manut pada pemerintah walau mereka punya tank sekalipun. 


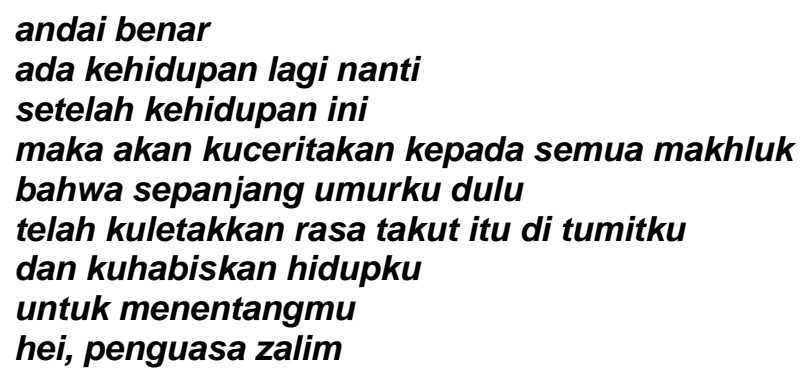

Pada baris-baris di atas, Wiji Thukul 'menyelipkan' metafora untuk mengungkapkan bagaimana situasi yang dialami pada masa tersebut. la menyebutkan rasa "takut", tetapi rasa takut ini justru menjadi bentuk kritikan. la menyebutkan bahwa rasa takut itu ia letakkan di tumitnya, menandakan bahwa rasa takut itu adalah hal yang remeh dan tetap kalah dengan semangatnya untuk menantang otoriteranisme pemerintah, yang dalam puisi ini tertulis pada kalimat terakhir, "hei, penguasa zalim". Sikap"

Perbandingan Kritik Sosial pada Puisi "Dari Catatan Seorang Demonstran" dan "Puisi

Puisi Dari Catatan Seorang Demonstran merupakan karya yang ditulis oleh Taufiq Ismail pada tahun 1966. Puisi tersebut merupakan sebuah cerminan sosial yang mengkritik pemerintahan pada masa karya tersebut ditulis, pemerintahan orde lama. Pada puisi tersebut, Taufiq Ismail menekankan suara rakyat yang merasa bahwa kebenaran tidak bisa dipertanggungjawabkan oleh pemerintahan Orde Lama. Kebenaran yang dimaksud berlandaskan segi politik, ekonomi, dan sosial terlebih mengenai HAM. Puisi membawa pandangan pengarang terhadap situasi yang dialami masyarakat ketika negerinya dipimpin oleh Soekarno. Puisi ini memiliki kesamaan dengan keadaan yang terungkap pada karya Wiji Thukul, Puisi Sikap. Puisi Puisi Sikap ditulis oleh Wiji Thukul pada tahun 1997, di mana pada masa tersebut Indonesia sedang mengalami krisis politik, ekonomi, dan sosial. Pada masa puisi Puisi Sikap ditulis, Indonesia berada di bawah pemerintahan Orde Baru yang dipimpin oleh Soeharto. Akibat kekacauan yang dialami oleh masyarakat semakin tinggi dan situasi politik yang tak terkendali, masyarakat menjadi lebih kritis dan tidak bisa lagi percaya pada pemerintahan.

Kedua puisi yang berbeda dari segi waktu, sama-sama menyuarakan perlawanan terhadap pemerintahan yang bertindak sewenang-wenang. Kedua puisi tersebut hadir untuk meruntuhkan sebuah rezim dan meluruskan sebuah sebuah sistem yang tidak selaras. Dari kedua puisi yang berasal dari dua orde yang berbeda memberi sinyal bahwa kedua orde tersebut membuat rakyat mempertanyakan kehadiran arti dari kemerdekaan bagi mereka. Indonesia memang sudah menyentuh kemerdekaan, tetapi perlawanan yang dihadapi oleh masyarakat membuktikan bahwa rakyat tidak merasa kemerdekaan berpihak pada mereka.

Kehadiran dua karya dari periode pemerintahan yang berbeda menunjukkan bagaimana pentingnya untuk mempertahankan prinsip demokratis pada negara. Menurut Suparno (2004:37) demokrasi membentuk nilai sikap yang tidak diskriminatif, yang mana demokrasi menjunjung tinggi kesetaraan hak setiap masyarakat. Setiap masyarakat mendapat hak dan perlakuan yang sama di mata negara tanpa memperhatikan bulu. Prinsip demokrasi memberikan kesetaraan hak dalam mengambil keputusan bagi kehidupan bermasyarakat. Pada hakikatnya, prinsip demokrasi menjadikan rakyat sebagai peran utama dalam proses politik. Hal ini seperti yang diungkapkan oleh Abraham Lincoln (dikutip di Silaban, dkk, 2013) mengenai tiga pilar penegak demokrasi yaitu pemerintahan dari rakyat (government of the people), pemerintahan oleh rakyat (government by the people), pemerintahan untuk rakyat (government for the people). Hal ini berbeda dari yang dialami oleh Taufiq Ismail dan Wiji Thukul. Kritik adalah salah satu cara yang bisa dilakukan masyarakat dalam melakukan perlawanan. Puisi Taufiq Ismail dan Wiji Thukul berperan sebagai wadah bagi kedua penyair menyalurkan opini serta ajakan dan ajaran bagi banyak orang. 


\section{PENUTUP}

KRITIK SOSIAL DALAM PUISI DARI CATATAN ...

Karya sastra merupakan hasil dari perenungan seorang pengarang mengenai fenomena yang ada atau bisa juga untuk menuangkan ide dan gagasan. Salah satu bentuk karya sastra yakni adalah puisi. Salah satu pendekatan yang bisa digunakan untuk mengkaji puisi yakni pendekatan sosiologis sastra, yaitu sebuah pemahaman terhadap karya sastra dengan mempertimbangkan aspek-aspek kemasyarakatannya. Berdasarkan uraian pada bab "hasil dan pembahasan" dapat ditarik kesimpulan bahwa dari perspektif sosiologis kritik sosial, puisi Dari Catatan Seorang Demonstran karya Taufiq Ismail dan Puisi Sikap karya Wiji Thukul terdapat aspek protes sosial terhadap pemerintah yang dianggap merugikan negara. Selain kekacauan dalam politik dan HAM, keduanya juga diakibatkan oleh kekacauan dalam perekonomian yang berdampak besar pada kehidupan masyarakat. Maka, menurut Peneliti, puisi berperan sebagai alat aspirasi untuk mengkritik pemerintah pada kedua peristiwa tersebut. Kedua penyair melakukan kritik terhadap kondisi sosial yang terjadi pada saat puisi tersebut ditulis.

\section{UCAPAN TERIMAKASIH}

Tim peneliti mengucapan terima kasih kepada lembaga penelitian STKIP Nurul Huda serta program studi Sastra Indonesia, Universitas Negeri Jakarta yang telah memfasilitasi pendidikan dalam membantu peneliti menyelesaikan artikel ini.

\section{DAFTAR PUSTAKA}

Aminuddin. 2011. Pengantar Apresiasi Karya Sastra. Bandung: Sinar Baru Algensindo.

Artika, I. W. 2015. Teori dalam Pengajaran Sastra. PRASI: Jurnal Bahasa, Seni, dan Pengajarannya. 10 (9). 18-27. https://ejournal.undiksha.ac.id/index.php/PRASI/article/view/8850

Damono, S. D. D. 1979. Sosiologi Sastra Sebuah Pengantar Ringkas. Jakarta: Depdikbud.

Hadi, P. K. 2009. Kritik Sosial dalam Antologi Puisi Aku Ingin Jadi Peluru Karya Wiji Thukul (Sebuah Tinjauan Sosiologi Sastra). FPBS IKIP PGRI Madiun. 15 (1) Diunduh pada situs http://ejournal.unipma.ac.id/index.php/JP/article/view/76

Harahap, S. R. (2013). Deteksi Dini Krisis Nilai Tukar Indonesia: Identifikasi Periode Krisis Tahun 19952011. Economics Development Analysis Journal. 2 (4). https://journal.unnes.ac.id/sju/index.php/edaj/article/view/3215

Ismail, T. 2005. Tirani dan Benteng. Jakarta: Yayasan Indonesia.

Jabrohim, dkk. 2009. Cara Menulis Kreatif. Yogyakarta: Pustaka Pelajar.

K, M.A., Mukti, M. A., \& Syahlulya, L. (2018). Kritik Sosial Dalam Kumpulan Puisi Karya Taufiq Ismail. Asas:Jurnal Sastra. 7(3). https://jurnal.unimed.ac.id/2012/index.php/ajs/article/view/10647

Luxemberg, J. V., Bal, M., \& Weststeijn, W. G. 1989. Edisi ke 3. Pengantar Ilmu Sastra. Diterjemahkan oleh D. Hartoko. Jakarta: PT Gramedia Pustaka Utama.

Linda Aprilia Kurniasari. Muhamad Sholehhudin. Joko Setiyono. (2019). Analisis Sosiologi Sastra Novel 'Sunyi Nirmala' Karya Ashadi Siregar dan Hubungannya Dengan Pembelajaran di SMA. Genre. 1(1). 46-51. http://journal2.uad.ac.id/index.php/genre/article/view/1061/587

Maman, S. \& Wiyatmi. 2012. Puisi Indonesia. Yogyakarta: Penerbit Ombak.

Oksinata, H. Kritik Sosial dalam Kumpulan Puisi Aku Ingin Jadi Peluru Karya Wiji Thukul. Surakarta: Fakultas Keguruan dan IImu Pendidikan. Universitas Sebelas Maret.

Putra, C. R. W.. (2018). Cerminan Zaman dalam Puisi (Tanpa Judul) Karya Wiji Thukul: Kajian Sosiologi Sastra. Kembara. 4(1). 12-20. https://ejournal.umm.ac.id/index.php/kembara/article/view/5873

Poerwadarminta, W.J.S. 1991. Kamus Umum Bahasa Indonesia. Jakarta: Balai Pustaka. 
Pradopo, R. D. 2014. Pengkajian Puisi. Yogyakarta: Gadjah Mada University Press.

Prakarsa, S. 2017. Perjuangan Angkatan 66 dalam Tuntutan TRITURA di Kota Jambi. Jambi:Perpustakaan Universitas Jambi.

Pratikno. 1998. Orde Baru dan Prospek Demokratisasi. Jurnal IImu Sosial dan IImu Politik. 2(2). https://jurnal.ugm.ac.id//isp/article/view/11152

Prayitno, H. W.. (2013). Peningkatan Keterampilan Menulis Puisi Menggunakan Teknik Inkuiri Dan Latihan Terbimbing. Jurusan Bahasa dan Sastra Indonesia, Fakultas Bahasa dan Seni, Universitas Negeri Semarang, Indonesia 2 (2) Diunduh pada situs https://journal.unnes.ac.id/sju/index.php/jpbsi/article/view/2399

Ratna, N. K. 2003. Paradigma Sosiologi Sastra. Yogyakarta:Pustaka Pelajar.

Sari, R. R. A. (2017). Kajian Struktur Puisi Karya Siswa Kelas V SDN Mrican 4 Kota Kediri Tahun Pelajaran 2016/2017. Jurnal Simki http://simki.unpkediri.ac.id/detail/13.1.01.10.0380

Setyorini, N. 2014. Aspek-Aspek Stilistika Novel Lalita Karya Ayu Utami. Bahtera. 1(2). 83-92. http://ejournal.umpwr.ac.id/index.php/bahtera/article/view/3495

Silaban, J. T., Yuwanto, L. Astrika. (2013). Persepsi Mahasiswa Fisip UNDIP terhadap Demokratisasi di Indonesia. Journal of Politic and Government Studies. 2(3) 386-395. https://ejournal3.undip.ac.id/index.php/jpgs/article/view/3086

Subandi. 2011. Deskriptif Kualitatif Sebagai Satu Metode dalam Penelitian Pertunjukan. Harmonia. 11(2). 173-179. https://journal.unnes.ac.id/nju/index.php/harmonia/article/view/2210/2272

Sutopo, HB. 2006. Metode Penelitian Kualitatif. Surakarta: UNS.Pres.

Soekanto, S. 2012. Sosiologi Suatu Pengantar. Jakarta: Rajawali Pers.

Wahyuningtyas, S. \& Santosa, W. H. 2011. Sastra: Teori dan Implementasinya. Surakarta: Yuma Pustaka.

Wellek, R. \& Warren, A. 1990. Edisi ke 2. Teori Kesusastraan. Diterjemahkan oleh : M. Budianta. Jakarta: Pustaka Jaya.

Wellek, R. \& Warren, A. 1995. Edisi ke 4. Teori Kesusastraan. Diterjemahkan : M. Budianta. Jakarta: Gramedia.

Yulianto, A. (2017). Kritik Sosial dalam Dua Cerita Pendek Karya Pengarang Kalimantan Selatan. BEBASAN. 4(2), https://jurnalbebasan.kemdikbud.go.id//urnal/index.php/bebasan/article/view/86 